\title{
The Development of Tertiary Education in Greece: The Determinant Factors
}

\author{
Stefanos Papailias ${ }^{1}$, Georgios Papakonstantinou ${ }^{2}$
}

\begin{abstract}
:
From the 1950s onwards, there has been a sharp increase in the number of students studying at higher education institutions both at European and global level. By 2000 in the developed countries of the West such as Sweden, Canada and the USA, 85\%-90\% of the population aged between 18 and 24 studied in post-secondary educational institution. This development could be attributed on the one hand to the role of the Welfare State and in particular the provision of free education and on the other, to the broader transformation of the global economy and the consequent emergence of demand for employees, white collars workers rather than blue collar ones. Greece has also exhibited a growth in the demand for higher education especially after the 1970s. During that period the expansion in the number of University and Technological Institutions was accompanied by a considerable increased tendency for students to study abroad in Europe and the USA. Indicatively, until recently Greece maintained the largest ratio of students over population studying abroad internationally. The causes are more of social rather than economical origin. The purpose of this paper is to investigate the factors that determine the phenomenon of increased demand for further studies in Greece. Furthermore there is an attempt to evaluate public as well as private expenditure as these emanate from the National Accounts and also household surveys. Moreover there will be an attempt to evaluate if the theory of Human Capital, regarding the return of investment, constitutes a critical factor to the decision for education. The data on which this paper is based originate from public sources (National Statistical Service) and also from empirical surveys conducted by the authors.
\end{abstract}

Key Words:

Secondary, Tertiary Education, Human Capital, Civil Servants, Total Earnings, Salaries, Greece

\footnotetext{
${ }^{1}$ PhD Candidate, National and Kapodistrian University of Athens, e-mail:stefpapailias@gmail.com

${ }^{2}$ Assistant Professor, National and Kapodistrian University of Athens, e-mail:gpapako@ppp.uoa.gr
} 


\section{Introduction}

\subsection{Human capital theory}

Many studies have been done and many researchers have referred to the theory of human capital mainly after 1950. J.C. Eicher recalls that in 1776, Adam Smith wrote: "The man who was educated by spending time and effort can provide work to reimburse the cost of education and at least a profit of capital of equal value" (Papakonstantinou, 2003). Schultz attributed the rate of economic growth of a country partly to education, while in the same decade researches from Universities of Chicago and Columbia of New York formulated the theory of Human Capital (Mincer, 1958, Schultz, 1961, Becker, 1964). "Investment in education yields the best interest", said Benjamin Franklin, long before Becker in 1964 published his book titled "Education is an investment", where he invented the term "Human capital".

According to the theory of human capital, it is not only material but also human resources that play an important role for the economic development of a country. Schultz (1961) supports that a person's knowledge and skills represent a form of capital. Human capital comprises all natural and acquired abilities of an individual, more specifically, natural abilities, talents, skills, knowledge and qualifications (Petrinioti, 1989). The acquisition and enrichment of human capital are time consuming and costly processes and results appear when the person begins to work (Psacharopoulos, 1999).

The prospect of employee participation in the educational system is regarded as a form of investment by the individual, his family and the society. Parents invest in their children in human and non-human (financial) capital. The poorest families tend to invest only in human capital because they are more "gainful" than the second (Becker and Tones, 1979). The individual, according to the theory, invests in education, in order to acquire a higher income in the future. For some time the more educated earns less money than the less educated, sacrificing the income that they would gain during this period in order to gain knowledge (Psacharopoulos, 1999).

\subsection{A Critical review: The theory of the filter}

Among the theories that have been formulated is that of the filter. It maintains that education has no direct effect on the productivity of individuals, and that human capital does not create, but testifies the most qualified, who are the most educated. This allows the employer to distinguish between the capable and the less capable employees. The fact that a prospective employee has a degree does not mean, according to this theory that he has learned more than one who does not have a degree, but has the necessary and sufficient skills that will make him a good worker in the production (Theocharakis, 2005). 
The theory of the filter contrary to that of human capital, while accepting the existence of a positive relation between education and wages does not accept that there is a causal link between them. For the particular theory education is the ticket to recruitment after the employers take into consideration the educational qualifications at the choice of their employees.

\section{The Benefits-Advantages of the Education}

\subsection{Benefits to the individual}

It is accepted by many researches that education yields not only direct but also indirect profits (Benhabib \& Spiegel, 1994, Berman et al., 1998, Mitrakos, 2004).

The direct private profits that derive from the education concerning the positive effects that the education of an individual has on his income, since through education the productivity of a worker is increased and that means increase of his wage (Psacharopoulos \& Patrinos, 2002).

According to the Organization for Economic Cooperation \& Development- OECD(2003), upper secondary and post-secondary non-tertiary education is in many countries the point beyond additional education level which is compensated with additional corresponding fee. Furthermore, the education level of an employee creates conditions of bigger labor stability and decreases the probabilities of unemployment (Bowen \& Finegan, 1969, Ashenfelter \& Ham, 1979, Mincer, 1993, Howe, 1993). According to the OECD (2012) research, the unemployment rate in 2010 was roughly one-third less for men with higher education than for men with upper secondary. Countries gain long-term economic and social benefits from investing more in education, the report conclude.

Indirect private returns of education are translated into better working conditions that the person with the highest education experiences work in an office with air conditioning or some private insurance covered by the company. (Psacharopoulos, 1999).

\subsection{Benefits to the society}

The positive effects of education benefit not only the person who is educated but also other members of the society as well as society itself. Firstly, studies have shown that democracy is strengthened, there is increased participation in the community and a critical stance is adopted as regards information presented by the media. Moreover, in a society comprised of more educated people there are more scientists, researchers, analysts, technicians and in general professional that increase and promote innovations through the production process with a view to the interest of the society. Additionally, it is worth mentioning that in such a society respect for 
the environment and social welfare prevail, while crime rates are significantly reduced (Grossman, 1976, Haveman \& Wolfe, 1984, Psacharopoulos, 1999).

\subsection{The contribution of education to economic growth}

There are many researches that confirm the positive relation between years of education and development (Denison, 1985, Barro, 1997, Hanusek \& Kimko, 2000). Various studies of the (OECD), agree with the findings of the aforementioned researches which attribute at least half of the increase in per capita GDP growth to labor productivity. In the long perspective, the impact of one additional year of education in the economic efficiency of countries (OECD, 2003) is in the order of $6 \%$. Furthermore, the survey results of recent years, conclude that policies aimed at improving the quality of provided education (Coulombe et al., 2004), as well as reducing educational inequalities (Mitrakos, 2004), can greatly contribute to longterm sustainable economic growth and to the weakening of economic inequality.

In conclusion, we could say that in the modern societies the education does not only have social and cultural purposes but also has economic usefulness because, through this particular process people not only acquire knowledge and skills in order to increase their "value" in the labor market, but also contribute decisively to the rate of economic growth of a country.

\section{The Cost of Education}

In order to yield profit, education requires long-term requirements both by the individual and by the society. The cost of investment in education is distinguished in:

- Private / personal cost: it is what concerns the educated person and it is analyzed in direct cost, namely the private tuition centers fees, private schools fees, expenses for purchase stationery, books, etc., and in indirect which is related with the foregone income of a person during his study, that is to say the money that would be acquired as income if the person were not being educated but worked (Psacharopoulos, 1999).

- Social cost: the money expended by the State for the education of the people. It is divided into direct and indirect. The direct social cost includes the functional expenses of education and the indirect the public cost investments in education (Psacharopoulos, 1999).

\section{An Empirical Research in Greece}

\subsection{Earnings of civil servants in Greece}

According to the law 4024/2011 of the Greek State, all newly appointed civil servants begin with seniority level $\mathrm{F}$. Those who possess a post-graduate degree 
related to the subject matter of their work classified at seniority level E, while those who possess a Ph.D. classified at level D.

A newly appointed employee with Compulsory Education (CE) in the Greek Public Sector receives 780 euro (level F) and this amount is considered the base which determines the starting monthly basic salaries of the rest of the categories (SE, TE). In Table 1 the starting monthly basic salaries of employees according to their education, are shown. If we multiply the starting salary by the following coefficients, we can calculate the salaries for the others categories.

Table 1: Starting monthly basic salaries of employees according to their education

\begin{tabular}{|l|l|l|l|}
\hline Category & Seniority level & Coefficients & Starting salary \\
\hline $\begin{array}{l}\text { (CE) Compulsory } \\
\text { Education }\end{array}$ & F & 1.00 & $780 €$ \\
\hline (SE) Secondary Education & F & 1.10 & $858 €$ \\
\hline (TE) Tertiary Education & F & 1.40 & $1,092 €$ \\
\hline
\end{tabular}

Source: Hellenic Republic Ministry of Finance, 2011

The starting monthly salary of a Secondary Education graduate and a Tertiary degree holder is $234 €$ and $312 €$ higher than that of a person with Compulsory respectively. Table 2 depicts the starting salaries of all categories of employees.

Table 2: The remaining starting salaries of all categories of employees

\begin{tabular}{|c|c|c|c|}
\hline Category & Seniority level & Increase $\%$ & Starting salary $(€)$ \\
\hline \multirow{4}{*}{$\mathrm{CE}$} & $\mathrm{F}$ & & 780 \\
\hline & $\mathrm{E}$ & $10 \%$ & 858 \\
\hline & $\mathrm{D}$ & $15 \%$ & 987 \\
\hline & C & $15 \%$ & 1,135 \\
\hline \multirow{5}{*}{ SE } & $\mathrm{F}$ & & 858 \\
\hline & $\mathrm{E}$ & $10 \%$ & 944 \\
\hline & $\mathrm{D}$ & $15 \%$ & 1,086 \\
\hline & $\mathrm{C}$ & $15 \%$ & 1,249 \\
\hline & $\mathrm{B}$ & $20 \%$ & 1,499 \\
\hline \multirow{6}{*}{ TE } & $F$ & & 1,092 \\
\hline & $\mathrm{E}$ & $10 \%$ & 1,201 \\
\hline & $\mathrm{D}$ & $15 \%$ & 1,381 \\
\hline & $\mathrm{C}$ & $15 \%$ & 1,588 \\
\hline & B & $20 \%$ & 1,906 \\
\hline & $\mathrm{A}$ & $10 \%$ & 2,097 \\
\hline
\end{tabular}

Source: Hellenic Republic Ministry of Finance, 2011 
As seen from the Table 2, the law does not allow an employee with Compulsory Education to reach the last two level of the hierarchy (B and A), while an employee with Secondary Education can reach up to level B. Comparing the salaries of an individual with Tertiary Education and that of one with Secondary, at the last level of the hierarchy, there is a difference of about $600 €(2,097 €$ over $1,499 €)$. Similarly, if we compare it with that of a person with Compulsory the additional amount that will be received by the employee with Tertiary Education reaches $962 €$ $(2,097 €$ and 1,135 respectively).

\subsection{Minimum time that is required to change seniority level (be promoted)}

Under the aforementioned law, the minimum time required for an employee with Compulsory education to reach the last level (C) is 22 years. The employee with Secondary education needs at least 22 years for the final level (B) he can reach, while the employee with University background needs at least 20 years to reach the top of the hierarchy, that is to say level A.

Table 3: Minimum time that is required to change seniority level (be promoted)

\begin{tabular}{|c|c|c|}
\hline Category & Seniority level & Years \\
\hline \multirow{3}{*}{ CE } & F & 2 \\
\cline { 2 - 3 } & E & 10 \\
\cline { 2 - 3 } & D & 10 \\
\cline { 2 - 3 } & C & At least 22 \\
\cline { 2 - 3 } & F & 2 \\
\cline { 2 - 3 } & E & 6 \\
\cline { 2 - 3 } & D & 6 \\
\cline { 2 - 3 } & C & At least 22 \\
\hline \multirow{5}{*}{ SE } & B & 2 \\
\cline { 2 - 3 } & F & 4 \\
\cline { 2 - 3 } & E & 4 \\
\cline { 2 - 3 } & D & 4 \\
\cline { 2 - 3 } & C & 6 \\
\cline { 2 - 3 } & B & At least 20 \\
\cline { 2 - 3 } & A & \\
\hline \multirow{5}{*}{ TE } & & \\
\hline
\end{tabular}

Source: Hellenic Republic Ministry of Finance, 2011

A conclusion that can be drawn from our findings, as it has been also highlighted by several economists, is that education plays a significant role in the earnings of an individual as well as in the social and work position he may hold.

It should also be stressed that only University degree holders can apply for one or two year studies in order to obtain a postgraduate title. This time will be deducted from the time required to reach the final level of the hierarchy (2 years). Similarly, for Ph.D. holders the time required to reach the last level of hierarchy is reduced by 6 years. 


\subsection{A model of the Greek civil servants total earnings}

In this section an example for the employees of the three main categories of employment depending on their education (CE, SE, TE) will be analyzed. It has been assumed that the working period is 40 years. The purpose of this model is to compare for a long term (40 years) the total salaries of the corresponding levels. From Table 4, it can be seen that an employee with Compulsory Education will receive in total 485,280 euro salary payment if he works for 40years. A Secondary education graduate who has actually studied 3 years more, will receive the amount of $610,440 €$, that is $125,160 €$ more.

When we compare the earnings of employees with the two previous categories of education to those of an employee with a Tertiary degree we see that the total compensation for 40 years of employment, adds up to $866,880 €$. That is to say, $381,600 €$ more than the employee with Compulsory education and $256,440 €$ more than the employee with Secondary.

Table 4: The total earnings of the Greek civil servants

\begin{tabular}{|c|c|c|c|c|}
\hline Category & Seniority level & Months & Salaries* $(€)$ & Total earnings $(€)$ \\
\hline \multirow{4}{*}{$\mathrm{CE}$} & $\mathrm{F}$ & 24 & 780 & 18,720 \\
\hline & $\mathrm{E}$ & 120 & 858 & 102,960 \\
\hline & $\mathrm{D}$ & 120 & 987 & 118,440 \\
\hline & $\mathrm{C}$ & 216 & 1,135 & 245,160 \\
\hline \multicolumn{4}{|c|}{ Total earnings for 40 years } & 485,280 \\
\hline \multirow{5}{*}{ SE } & F & 24 & 858 & 20,592 \\
\hline & $E$ & 72 & 944 & 67,968 \\
\hline & $\mathrm{D}$ & 72 & 1,086 & 78,192 \\
\hline & C & 96 & 1,249 & 119,904 \\
\hline & B & 216 & 1,499 & 323,784 \\
\hline \multicolumn{4}{|c|}{ Total earnings for 40 years } & 610,440 \\
\hline \multirow{6}{*}{$\mathrm{TE}$} & $\mathrm{F}$ & 24 & 1,092 & 26,208 \\
\hline & $E$ & 48 & 1,201 & 57,648 \\
\hline & $\mathrm{D}$ & 48 & 1,381 & 66,288 \\
\hline & $\mathrm{C}$ & 48 & 1,588 & 76,224 \\
\hline & $\mathrm{B}$ & 72 & 1,906 & 137,232 \\
\hline & A & 240 & 2,097 & 503,280 \\
\hline \multicolumn{4}{|c|}{ Total earnings for 40 years } & 866,880 \\
\hline
\end{tabular}

*Salaries are in gross value

\section{How Much a Student Costs to the Greek Household}

\subsection{Evening private classes}

In Greece, although education is by law public and free for all, at the beginning and during each school year households spent part of their family budget on school supplies and education services (evening private classes, foreign language schools, private lessons, etc.). It is customary to begin these evening private classes, even to a 
mild degree, in the first years of junior high school (junior high school is part of Compulsory education). Throughout Secondary education (senior high school) evening private classes are intensified, and usually the average student spends there between 10 hours per week for the first year and reach 16 hours for the final year.

From a survey that was conducted ${ }^{3}$ by the authors in 30 random private institutions that offer (senior high school level) private classes ${ }^{4}$ it is established that the average tuition fees for a first grade student are 2,302€, for a student at the second grade parents will have to pay $2,579 €$ while in the last grade the sum is yet increased and reaches approximately 3,500 € per year. The total sum of the three classes for these evening private classes throughout senior high school which the Greek household is required to pay for each teenager is $8,320 €$.

Additionally, according to the evaluation of KE.P.KA ${ }^{5}$ (2012) the average cost of stationery (school supplies, school bags, foreign language books, teaching aids) for a school year per student reaches $200 €$.

\subsection{Foreigner languages evening private classes}

According to results of research ${ }^{6}$ as well as data from ISTAME (2006), a student, in order to acquire to a good level of English knowledge, needs to attend English language classes for at least 6 years, in which case the cost to the family budget touches almost 7,000 €. A certificate in foreign languages is usually obtained during any of the three grades of Senior High School (Secondary education). It is assumed that a student who only attends compulsory education has basic knowledge of English and does not need to learn more. So the cost of attending foreign language private evening classes is not calculated for someone who attends Compulsory education.

\subsection{Assessment of foregone income: Evening private classes fees}

Foregone income is defined as the sums of money which a person would earn if instead of studying he continued to work. We assume that a Compulsory Education graduate begins work at the age of 15 , while a Secondary education graduate begins work at 18. If it is assumed that during these three years the new employee ${ }^{7}$ is paid with the minimum salary, estimated at 550-600 € a month, then his total earnings

\footnotetext{
${ }^{3}$ The sample period concerns the prices of the school year 2011-2012.

4 The sample of evening private classes found from the Observatory Tuition of the Ministry of Development, Competitiveness and Shipping, General Secretariat of Commerce.

${ }^{5}$ Consumer protection center

${ }^{6}$ We based our analysis on a random sample of 20 foreign languages centres for the 20112012 school year.

${ }^{7}$ Only those over 18 can be hired in the Public Sector, so in this case it is considered that the person works in the Private Sector.
} 
will fluctuate between around 19,800 € and 21,600 $€$. In Table 5 the total indicative cost of studies for a person who wants to continue his studies in Secondary Education is presented.

Table 5: The total indicative cost of studies for a person who wants to continue his studies in Secondary Education

\begin{tabular}{|l|c|}
\hline Expenditure categories & Amount $(€)$ \\
\hline Secondary Education evening private classes & 8,320 \\
\hline Foreign language evening private classes & 7,000 \\
\hline Stationery & 600 \\
\hline Foregone income & 20,700 (on average) \\
\hline Total Expenditure & $\mathbf{3 6 , 6 2 0}$ \\
\hline
\end{tabular}

Assuming that other factors (increase of salary, services, goods, promotion to a senior post with higher earnings, etc.) remain unchanged, we could generally conclude that the benefits of education to financial rewards are as presented in the following indicative Table 6 .

Table 6: The benefits of education to financial rewards

\begin{tabular}{|l|c|}
\hline Difference of total salaries between SE and CE & $125,160 €$ \\
\hline Total expenditure & $36,620 €$ \\
\hline Net profit & $\mathbf{8 8 , 5 4 0 €}$ \\
\hline
\end{tabular}

Taking into consideration the data in Table 4, the additional amount that will be gained by a Secondary Education graduate compared to that of a Compulsory education graduate, amounts to approximately $125,000 €$. If the expenses required for three further years of education $(36,620 €)$ are deducted, the profit generated reaches approximately $89,000 €$.

\subsection{The cost of tertiary education studies}

A great number of students who continue their studies in Third degree Institutions are forced to "migrate" mostly in but also outside the country. In this Section, the costs related to the students who "migrate" to a place in Greece will be taken into consideration. Based on previous researches (Papaelias, 2006 and Katsikas 2009), the average time period needed to obtain a university degree is 5.5 years ${ }^{8}$. The average monthly cost of living outside the city of his permanent residence for a student amounts to $1,000 €$. In Table 7 the monthly living expenses are presented.

\footnotetext{
${ }^{8}$ Studies in Agriculture, Forestry, Polytechnic School etc, last five years. Most researchers assume that on average studies are completed in six years.
} 
Table 7: The monthly living expenses

\begin{tabular}{|l|c|}
\hline Accommodation rental & $350 €$ \\
\hline Food, transportation & $300 €$ \\
\hline Purchases & $100 €$ \\
\hline Entertainment & $150 €$ \\
\hline Various expenses & $100 €$ \\
\hline Total expenses & $1,000 €$ \\
\hline
\end{tabular}

Source: Katsikas, 2009

If we assume that the average time needed to obtain a degree is 5.5 years and multiply this by the annual living expenses of a student that we have just presented, then the amount that must be paid from the family budget exceeds $60,000 €$.

Table 8 shows the profit that a Tertiary education graduate has, compared to a Secondary and Compulsory education graduate. It has been deducted the extra education expenditure required for a University degree ${ }^{9}$.

Table 8: The profit that a Tertiary education graduate has

\begin{tabular}{|l|c|l|c|}
\hline $\begin{array}{l}\text { Difference of total salaries } \\
\text { between TE and SE }\end{array}$ & $256,440 €$ & $\begin{array}{l}\text { Difference of total salaries between } \\
\text { TE and CE }\end{array}$ & $381,600 €$ \\
\hline $\begin{array}{l}\text { Total expenses of student } \\
\text { in-migrants }\end{array}$ & $60,000 €$ & $\begin{array}{l}\text { Total Expenditure, foregone } \\
\text { income etc }\end{array}$ & $36,620 €$ \\
\cline { 2 - 4 } & $\begin{array}{l}\text { Cost of foregone income from } \\
\text { employment }\end{array}$ & $54,756 €$ \\
\hline $\begin{array}{l}\text { Cost of foregone income } \\
\text { from employment }\end{array}$ & $\mathbf{6 0 , 2 4 0 €}$ & $\begin{array}{l}\text { Total expenses of student in- } \\
\text { migrants }\end{array}$ & $60,000 €$ \\
\hline Net profit & $\mathbf{1 3 6 , 2 0 0 €}$ & Net profit & $\mathbf{2 3 0 , 2 2 4 €}$ \\
\hline
\end{tabular}

Summarizing, it is concluded that the financial benefit for someone who has finished Tertiary education compared to one who has graduated from Secondary and Compulsory, touches approximately $136,000 €$ and $230,224 €$ respectively.

\section{Conclusion}

The purpose of this study is to highlight the earnings difference among graduates of various levels of education. The examples that have been presented as well as the comparisons made refer to the Greek Public Sector and this is because there is a common civil servant code which leads to more valid comparison results.

\footnotetext{
${ }^{9}$ Provided that -like most people in Greece- they study in a place away from their home

${ }^{10}$ It is considered, that on completion of Secondary education and after the age of 18 the person works in the Public Sector and the total earnings are measured in accordance with Table 4.
} 
In the private sector, although there are differences in the salaries received depending on the employees' level of education and according to labor agreements voted by the parliament, there are still companies, especially small ones that do not pay their employees extra for any higher education certificate they may have. This is mainly a problem for masters' and PhD holders. There are quite a lot of students who, on completion of their postgraduate studies abroad, decide to look for employment in the foreign country since not only will they have a better salary but also their investment in further education will be better paid than if they looked for employment in Greece. Especially nowadays that we live in times of recession, these problems become more pressing.

Finally, we should highlight the necessity for education for the whole of the society, not only for the earning differences that it entails but also for the social and cultural benefits that stem from it.

\section{References}

Ashenfelter, O. and Ham, J. (1979), "Education, Unemployment and Earnings", Journal of Political Economy, 87(5), pp. 99-116.

Barro, J. (1997), Determinants of Economic Growth: A Cross-section Empirical Study, MIT Press.

Becker, G. (1964), Human Capital: A Theoretical and Empirical Analysis with SpecialReference to Education, The University of Chicago Press, 3rd ed., Chicago.

Becker, G. (1993), Human Capital, University of Chicago Press, $3{ }^{\text {rd }}$ Edition, Chicago.

Becker, G. and Tones, N. (1979), "An Equilibrium Theory of the Distribution of Income and Intergenerational Mobility”, Journal of Political Economy, Vol. 87.

Benhabib, J. and Spiegel, M. (1994), "The role of Human Capital in Economic Development", Journal of Monetary Economics, 34(2), pp. 147-174.

Berman, E., Bound, J. and Mashin, S. (1998), "Implications of Skill - Based Technical Change: International Evidence", Quartely Journal of Economics, 113(4), pp. 12451279 .

Bowen, W. and Finegan T. (1969), The Economics of Labor Force Participation" Princepton, Princepton University Press.

Coulombe, S., Trempblay, F. and Marchand, S. (2004), Literary Scores, Human Capital and growth Across Fourteen OECD Countries, Statistics Canada.

Denison, F. (1985), Trends in American Economic Growth, 1929-1982, Washington: Brooking Institution.

Grossman, M. (1976), The Correlation Between Health and Schooling in Household Production and Consumption, New York: National Bureau of Economic Research.

Hanusek, E. and Kimko, D. (2000), "Schooling, Labor-force quality of the growth of nations", American Economic Review, 90(5), pp. 118-208.

Haveman, R. and Wolfe, B. (2004), "Schooling and Economic Well-Being: The Role of Non-Market Effects”, Journal of Human Resources, 19(1), pp. 377-407. 
Howe, J. (1993), The Effect of Higher Education and Economic Growth, Academic Publishers, pp. 129-144.

Mincer, J. (1958), "Investments in Human Capital and Personal Income Distribution", Journal of Political Economy, 66(4), pp. 281-302.

Mincer, J. (1993), "Education and unemployment in studies in human capital", National Bureau of Economic Research, 3838, Cambridge, UK: Edward Elgar Publishing.

Mitrakos, Th. (2004), "Education and Economic Inequalities", Economic Bulletin, Bank of Greece, 23, pp. 33-50.

Papaelias, Th. (2006), Education in the frame of globalization, Athens: Stamoulis.

Papakonstantinou, G. (2003), Supply and demand of higher education, Athens: Metaixmio.

Petrinioti, X. (1989), Labor Markets”, Athens: Papazisis.

Psacharopoulos, G. (1999), "Economy of Education, Athens: Papazisis.

Psacharopoulos, G. and Patrinos, H. (2002), Returns to Investment in Education: A further Update, Policy Research Working Paper, 2881.

Schultz, T.W. (1961), "Investment in Human Capital", American Economic Review, 51(1), pp. 1-17.

Theocharakis, N. (2005), The Neoclassical Theory of Labor: A Review in the light of economic thought, Athens: Dardanos. 